\title{
Finding New Ways of "Doing" Socio-Legal Labor Law History in Germany and the UK: Introducing a "Minor Comparativism"
}

\author{
Rebecca Zahn*
}

(Received 07 September 2020; accepted 13 September 2020)

\begin{abstract}
Labor law scholars have been receptive to socio legal methods, going beyond doctrinal legal sources and looking to other disciplines including industrial relations, sociology, and history. This Article revisits the development of socio legal labor law scholarship in Germany and the UK in order to understand the different approaches within the context of two different legal and academic cultures, and considers how a comparison can provide new insights at a time when the discipline is in a state of flux. In particular, this Article focuses on how history can provide an entrée into different ways of comparing labor law and labor relations systems. It seeks to start a methodological debate on "how to do" labor law history within the context of the discipline's socio legal origins. In a final section, it uses insights from history and comparative law in order to develop a new methodology-a "minor comparativism"-which unearths the processes and influences underpinning the historical development of labor law which have hitherto escaped the legal record. Such an approach enables scholars to reassess traditional narratives-a worthwhile endeavor at a time when the future role of labor law in regulating work is under scrutiny.
\end{abstract}

Keywords: Labor law; comparative law; legal history; labor history

\section{A. Introduction}

Labor law, comprising individual employment laws and the collective regulation of work by trade unions and employers at different levels, lends itself to socio-legal approaches. Labor law not only involves the legal regulation of the work relationship, but also broader policy choices about the nature of society and the distribution of resources. Any sophisticated study of the discipline mandates an understanding of labor law's legislative content as well as the historical, social, political, and economic context within which it has evolved, and within which its legislation plays out. Thus, labor law scholars have been receptive to socio-legal methods-going beyond doctrinal legal sources and looking to other disciplines including industrial relations, sociology, and history. Many scholars are committed to legal pluralism in recognizing the involvement of nonstate actors such as trade unions and employer associations in law creation and law enforcement. ${ }^{1}$ Yet the decline of the old industrial order since the latter half of the twentieth century, and the transformation of work and production, have triggered a debate amongst labor law academics about the

\footnotetext{
${ }^{*}$ Rebecca Zahn is a Senior Lecturer in Law at the University of Strathclyde. The author would like to thank the editors of this Special Issue for comments on earlier drafts. The usual disclaimer applies.

${ }^{1}$ See generally Ruth Dukes, Critical Labour Law: Then and Now, in ReSEARCH HANDBOOK On CRITICAL LEGAL THEORY 345, 349 (Emilios Christodoulidis et al. eds., 2019); Karl Klare, Horizons of Transformative Labour Law, in LABOUR LAW IN AN ERA of Globalisation (Joanne Conaghan et al. eds., 2004).
}

(C) The Author(s), 2020. Published by Cambridge University Press on behalf of the German Law Journal. This is an Open Access article, distributed under the terms of the Creative Commons Attribution licence (http://creativecommons.org/licenses/by/4.0/), which permits unrestricted re-use, distribution, and reproduction in any medium, provided the original work is properly cited. 
future of capitalism and labor law's role within it. Scholars have struggled to define the discipline's institutional and normative weight in the face of globally integrated markets and a drastically changed regulatory environment. There is a recognition, particularly amongst British labor law scholars, that "old ways of thinking about the subject, of describing and analyzing it, [seem] increasingly inadequate, but new ways have yet to be found."

Contributing to this special issue provides an opportunity to revisit the development of socio-legal labor law scholarship in Germany and the UK, to understand the different approaches within the context of two different legal and academic cultures, and to consider how a comparison can provide new insights at a time when the discipline is in a state of flux. This Article focuses in particular on how history can provide an entrée into different ways of comparing labor law and labor relations systems. While early labor law scholars in Germany and the UK relied on history to develop new understandings for the discipline, few contemporary academic labor lawyers would identify as labor law historians. ${ }^{3}$ There is no institutional infrastructure or identifiable community of scholars dedicated specifically to the field-in the sense of scholars who share common understandings about the subject matter, including its methodological requirements. ${ }^{4}$ The scope of the field itself remains unclear, both substantively and temporally. It straddles labor history and legal history, but lacks a home of its own - as scholars who research medieval laws on master and servant are more likely to attend legal history conferences than labor law conferences. ${ }^{5}$ Since the 1960s, there has been a rise in labor history scholarship which has looked at working-class experience more broadly where topics overlap with labor law. ${ }^{6}$ However, labor historians "have only occasionally engaged with twentieth century labor law,"7 and their work has never become part of mainstream labor law scholarship. Indeed, it is only occasionally cited by those working on labor law history. A consequence of the blurring of boundaries and lack of a distinct community amongst labor law historians is that there have been limited reflections on the foundational question of "how to do" labor law history within a national and comparative context in both Germany and the UK. Eric Tucker aptly suggests that labor law historians "ain't got no home," and that there has been "limited development of a collective identity which in turn has failed to produce the institutional infrastructure that would support greater reflection on methodological issues in the field."

This Article seeks to start a methodological debate on "how to do" labor law history within the context of the discipline's socio-legal origins. It uses insights from history and comparative law in order to develop a new methodology, a "minor comparativism," which unearth the processes and influences underpinning the historical development of labor law which have hitherto escaped the legal record. A minor comparativism enables scholars to adopt the perspective of those who were minorities - in the sense of being powerless - within their own country. In doing so, it encourages alternative ways of thinking about traditional narratives by revealing the views of minority groups whose ideas were not translated into law. Such an approach enables scholars to reassess traditional narratives - a worthwhile endeavor at a time when the future role of labor law in regulating work is under scrutiny.

\footnotetext{
${ }^{2}$ Dukes, supra note 1, at 354 (citing The IdEA OF LABOR LAW (Guy Davidov \& Brian Langille eds., 2011)).

${ }^{3}$ See generally Eric Tucker, On Writing Labour Law History: A Reconnaissance, 33 INT'L J. COMP. LAB. L. \& INDUs. REL. 39 (2017) (for an overview of the literature).

${ }^{4}$ Writing labor law history is not necessarily dependent on the establishment of such a community. However, the successful establishment of a field of study is often marked by the creation of an institutional infrastructure, including academic societies, regular conferences, and dedicated journals. See generally id.

${ }^{5} I d$. at 44 .

${ }^{6}$ See generally Joan Allen et al., Histories of Labour. National and International Perspectives (2010).

${ }^{7}$ Id. at $106-07$.

${ }^{8}$ Tucker, supra note 3 , at 42 .

${ }^{9}$ See generally Sherally Munshi, You Will See My Family Become so American: Toward a Minor Comparativism, 63 Am. J. CoMP. L. 655 (2015).
} 
The Article proceeds as follows. Sections B and C revisit the development of socio-legal, or historical, labor law scholarship in Germany and the UK. Section B finds that there is an openness, to varying degrees, in both systems to socio-legal approaches. Though the tradition of socio-legal labor law scholarship originated in Germany, it has embedded itself in the UK. Section C presents a short history of labor law history in both countries. Again, there is an openness to socio-legal approaches, but there has been limited engagement with methodological questions. Labor law history lacks a debate on its relationship with socio-legal studies more broadly. In Sections D and E, I begin to develop a methodology for labor law history within a socio-legal framework, based on comparative law and drawing on historical sources and methods. Section $\mathrm{D}$ situates the methodology within comparative law and introduces the concept of a minor comparativism. Section E illustrates the possible uses of a minor comparativism by summarizing my current research project on worker participation in workplace decision-making, followed by a conclusion.

\section{B. The Development of the Socio-Legal Study of Labor Law}

There is an established tradition of socio-legal labor law scholarship which emerged first in Germany, and later in the UK. In Germany, Hugo Sinzheimer (1875-1945) played a major role in developing a theory of German labor law during the Weimar Republic. Sinzheimer considered labor law as a tool to be manipulated to correct the injustices inherent in the capitalist mode of production. ${ }^{10}$ He supported Rudolf Stammler's theory according to which "law" represents the "moulding force" of social life: "Society does not exist in a preconstituted form," but "is 'guaranteed' by law." "For Sinzheimer, this meant that the "law"- as contained in legislation and court judgments - was not just a system of norms, but also had to correspond to the social needs for which it was developed. Thus, law had to be understood within the context of "legal reality," or, the norms which govern social action. Any analysis of labor law had to adopt a socio-legal method. ${ }^{12}$

Sinzheimer's advocacy for the socio-legal method in labor law fed into the Methodenstreit of the 1930s, which pitched the socio-legal method against the "law as science" approach - the latter supported by a number of leading German labor law scholars, including Hans Carl Nipperdey and Walter Kaskel. ${ }^{13}$ The "law as science" approach stressed objectivity in legal analysis—rejecting any "politico-legal" treatment of labor law, which it considered a "step backwards to a kind of sociological feuilleton"14 — and instead adopted a legal dogmatic lens. ${ }^{15}$ It systematically divided labor law "into several components (together with industrial insurance, labor contracts, labor protection, labor constitution (Arbeitsverfassung), the public authorities with regard to work and trade disputes, as well as the 'search' for work (Arbeitsbeschaffung) and help for the unemployed)." 16 Labor law was studied and taught in an aprioristic manner. Sinzheimer broke with this systematization, by interpreting labor law in a way that clarified "the processes going towards its making, starting with the structures and functioning of rival social forces."

\footnotetext{
${ }^{10}$ See generally Ruth Dukes, The Labour Constitution: The Enduring Idea of Labour Law (2014).

${ }^{11}$ See generally Rudolf StAmmLer, WirTschaft und Recht (1986); Luca Nogler, In Memory of Hugo Sinzheimer (1875-1945): Remarks on the Methodenstreit in Labour Law 2 CARDOZO L. Bull. (1996), www.jus.unitn.it/cardozo/review/ laborlaw/nogler-1996/nogler.htm.

${ }^{12}$ Nogler, supra note 11.

${ }^{13} I d$. On the Methodenstreit in law more generally, see Michael Stolleis, Der Methodenstreit Der Werimarer Staatsrechtslehre - Ein Abgeschlossenes Kapitel Der Wissenschaftsgeschichte? (2001).

${ }^{14}$ See Walter Kaskel, Recht Und Wirtschaft 70-71 (1922).

${ }^{15}$ See also Sandro Blanko, Soziales Recht Oder Kollektive Privatautonomie: Hugo Sinzheimer Im Kontext NACH 1900 Ch. 2 (2005), 67-100.

${ }^{16}$ KASKEL, supra note 14 , at 71-72.

${ }^{17}$ Nogler, supra note 11 (citing Franz Mestitz, Alcuni ricordi di Hugo Sinzheimer, in Lavoro E DiRITTO 1 (1989)).
} 
As a prominent Jewish scholar, Sinzheimer was forced to leave Germany for the Netherlands in 1933 and died in exile in 1945. Following World War II, Sinzheimer's approach was not initially resurrected. Labor law lacked the foundational, legal-political debate on its role and purpose which had defined the Weimar Republic. It was characterized by a "withdrawal to general clauses" and a reliance on "judge-made laws." 18 Labor laws and the accompanying jurisprudence were based on the principles of social and mutual cooperation which tempered collective articulation and action. ${ }^{19}$ As Ramm explains, "[a]fter 1945 labor law was deprived of its left wing politics and Jewish scholars; it was a labor law in which the force of the workers' movement was lacking, as was the social issue." ${ }^{20}$ A change in approach only occurred in the 1970s when a group of younger scholars reignited the Methodenstreit of the inter-war years by calling for labor law to consider the law as it exists in society. ${ }^{21}$ This group of scholars - the "labour law left" (die arbeitsrechtliche Linke), a minority in labor law scholarship_-presented their arguments as a rigorous rebuttal of the majority's legal dogmatic arguments. They adopted a broad definition of labor law as including the law as contained in legislation and judicial decisions as well as its impact on the work relationship. The arbeitsrechtliche Linke advocated a more politicized approach to labor law, analyzing the law through recourse to socio-legal methods. ${ }^{22}$ In doing so, they revived a foundational, and still ongoing, debate on the role and purpose of labor law scholarship. Coupled with changes in the labor market that have led to a decline in the standard employment relationship, there has been a recognition in Germany that labor law scholarship must respond "to problems of daily life and away from abstract theory or, as it is called, Dogmatik," ${ }^{23}$ thereby opening up potential avenues for future socio-legal research projects.

Although his influence has been limited in his home country, Sinzheimer's socio-legal approach had an effect beyond Germany. Otto Kahn-Freund (1900-1979), the "founding father" of British labor law and one-time student of Sinzheimer, had internalized his teacher's thinking. ${ }^{24}$ Kahn-Freund's main contribution to the creation and development of British labor law was his articulation of the doctrine of collective laissez-faire, which states that the central function of British labor law is to enable, facilitate, and support the regulation of the employment relationship through voluntary collective bargaining between employers and trade unions. As Davies and Freedland explain:

At the heart of Otto Kahn-Freund's thinking about labor law was an ideology of collective bargaining .... It was an ideology in the sense of being a set of ideas that assumed systematic proportions, that is to say was regarded as a basis for thinking about labor law and labor relations as a composite conception that embraced both the practice and the regulation of the employment relationship. ${ }^{25}$

This sociological approach to thinking about labor law à la Sinzheimer embraced both "the law" and the "actual state of affairs." 6 In order to determine "the actual state of affairs," Kahn-Freund collaborated with a number of industrial relations scholars, particularly the

\footnotetext{
${ }^{18}$ Ramm speaks of a "Flucht in die Generalklauseln" und "richterliche Rechtsfortbildung." See Thilo Ramm, Die "Linke" und das Arbeitsrecht, 33 JURISTEN ZEITUNG 184, 185 (1978).

${ }^{19}$ See generally Thilo Ramm, Codetermination and the German Works Constitution Act of 1972, 3 INDUs. L.J. 20 (1974).

${ }^{20}$ Thilo Ramm, Pluralismus ohne Kodifikation. Die Arbeitsrechtswissenschaft nach 1945, in RECHTSWISSENSCHAFT IN DER BONNER REPUBLIK 456 (Dieter Simon ed., 1994).

${ }^{21}$ See generally Wolfgang Däubler, Arbeitsrechtliche Forschung in der Bundesrepublik, in WsI MITTEILUNGEN 67 (1985).

${ }^{22}$ See generally Ramm, supra note 18.

${ }^{23}$ Rolf Birk, Labour Law Scholarship in Germany, France and Italy, 23 CoMP. LAB. L. \& PoL’y J. 679, 686 (2002).

${ }^{24}$ See generally DuKES, supra note 10.

${ }^{25}$ Paul Davies \& Mark Freedland, National Styles in Labor Law Scholarship: The United Kingdom, 23 COMP. LAB. L. \& POL'Y J. 765, 766 (2002).

${ }^{26}$ See generally DUKES, supra note 10.
} 
"Oxford School" led by Allan Flanders and Hugh Clegg-scholars who had an interest in and understanding of the history of industrial relations. ${ }^{27}$ The resulting multi-disciplinary labor law scholarship sought to analyze and explain legal rules within their social context. Although this particular type of British labor law scholarship had its heyday in the 1960s, it produced an extended generation of labor law scholars who followed in Kahn-Freund's footsteps. ${ }^{28}$ Many of these scholars drew on the writings of labor historians and industrial relations scholars in order to explain and develop labor law. Their work placed "labor law at the cutting edge of British socio-legal scholarship."

Subsequent shifts in government policy have meant that collective laissez-faire as a key feature of British labor law has all but disappeared, and as such, new rationales for, and ways of thinking about, labor law have emerged. Yet British labor law scholarship stands out for retaining an open, multi-disciplinary approach. There has not been the development of a single dogmatic framework which guides analyses. ${ }^{30}$ Contemporary researchers have turned to philosophy and political theory, economics, sociology, and political economy approaches in order to explain and advance the discipline at a time when the labor market has fundamentally changed. ${ }^{31}$ This Article proposes to use history as an entrée into developing different ways of understanding the origins and future trajectory labor law and labor relations systems. As a prerequisite for this approach, the next section reviews the labor law history scholarship in Germany and the UK.

\section{A History of Labor Law History in Germany and the UK \\ I. The UK}

Labor law history in the UK lives at the margins and intersections of a number of different fieldsincluding labor history, legal history, labor law, and industrial relations. The extent to which scholars have adopted an explicitly socio-legal approach - in the sense of going beyond doctrinal sources-appears to be driven by individual project considerations-including researchers' historiographic and theoretical commitments - rather than being shaped by discipline-wide methodological debates - which have hitherto been lacking. Labor law history emerged, along with labor history, in the late nineteenth and early twentieth centuries among scholars interested in the "labor question," centered on the role of workers' collective action. ${ }^{32}$ Early labor law histories traced the legal regulation of trade unions. ${ }^{33}$ Labor law history has thus traditionally been situated within an industrial relations framework-although labor law and industrial relations have parted ways as the former has responded to shifts in government policy away from collective laissez-faire and the latter has focused increasingly on quantitative methodologies, becoming a "largely history-free field fundamentally concerned with policy in the present." ${ }^{34}$ As a result, labor law history

\footnotetext{
${ }^{27}$ See Clegg's three-volume work, in particular, on the history of trade unions which combined industrial relations and labor history, I-III H.A. ClegG, A History of British Trade Unions Since 1889 (published between 1964 and 1994). Industrial relations subsequently turned away from history and developed as a specialized, largely history-free field fundamentally concerned with policy in the present. See generally ALLEN ET AL., supra note 6.

${ }^{28}$ These include Bill Wedderburn, Paul O'Higgins, Bob Hepple, and to some, though perhaps a lesser extent, Roger Rideout, Steve Anderman, Roy Lewis, Jon Clark, Paul Davies, and Mark Freedland. See Davies \& Freedland, supra note 25, at 769.

${ }^{29} I d$.

${ }^{30} \mathrm{Id}$. at 786.

${ }^{31}$ See generally The Philosophical Foundations of Labour Law (Hugh Collins et al. eds., 2018); Keith D. Ewing, Democratic Socialism and Labour Law, 24 InDUS. L.J. 103 (1995); Georg Menz, Employers and Migrant Legality: Liberalization of Service Provision, Transnational Posting, and the Bifurcation of the European Labour Market, in Migrants AT Work (Cathryn Costello \& Mark Freedland eds., 2015); Ruth Dukes, The Economic Sociology of Labour Law, 46 J.L. \& Soc'y 396 (2019).

${ }^{32}$ Tucker, supra note 3 , at 42 .

${ }^{33}$ See generally Sidney \& Beatrice Webb, The History of Trade Unionism (1894); Robert Yorke Hedges \& Allan Winterbottom, The Legal History of Trade Unionism (1930).

${ }^{34}$ AlLEN ET AL., supra note 6, at 107.
} 
differs in its origins and approach from legal history, which has traditionally produced narrow "internal histories" of law with an emphasis on the common law. ${ }^{35}$

Legal history's purpose has been to recreate the particular contexts which shaped the law by, inter alia, reading marginalia, case notes, personal papers, government reports, newspaper articles, and other, often archival, materials which normally evade the attention of other legal scholars, in order to fully capture the contexts surrounding the law. ${ }^{36}$ Labor law historians, by contrast, do not produce "internal" histories in the sense understood by the legal historian, but analyze labor law history in relation to wider social forces. Labor law historians have walked a fine line between law and politics. Often, the purpose of adopting a historical lens has been to better understand the law with a view to making reform proposals. ${ }^{37}$ The most extensive analysis of labor law history can be found in Lord Wedderburn's The Worker and the Law. Published in 1965, it explained the whole legal framework governing labor in an historical and sociological context. ${ }^{38}$ As Hepple explains, "Wedderburn came to labor law through his private reading of labor history." 39 He relied on a wide range of materials, including extracts from judicial decisions and decisions of national insurance commissioners, government ministers, the Registrar of Friendly Societies, collective agreements, union rule books, fair wages resolutions, and other documents not commonly used in traditional black-letter law books. ${ }^{40}$ Subsequent editions of the book maintained the contextual, historical focus to explain legal developments. ${ }^{41}$ As Hepple points out, "Wedderburn found that the history books' accounts of [labor law's development] were inadequate. His special contribution to the history of labor law and industrial relations ... was to synthesize the history of legal doctrine and social history." 42

A handful of other scholars have also written on labor law history over the last thirty years, taking as their starting point the different historical and social forces which have shaped labor law - which is understood broadly to include legislation, case law, regulations and customs. Their methodological choices have been guided by the purpose of individual projects. In 1993, Paul Davies and Mark Freedland wrote a history of British labor legislation between 1945 and $1990 .{ }^{43}$ They explicitly situated their legislative history within a legal framework-rather than seeking "to operate as historians or social scientists"44_taking into account that law is "a product of the formulation and application of governmental economic and social policies." 45 By way of contrast, Keith Ewing has made extensive use of archival materials and social and economic history literature. His book, Trade Unions, the Labour Party and the Law, consulted a wide range of sources to study the Trade Union Act of 1913 from historical and legal perspectives with a view to understanding the legislation's origins and effects within its broader social context. ${ }^{46}$ In an article published in 1998, Ewing presented a reassessment of Kahn-Freund's account of collective

\footnotetext{
${ }^{35}$ See Sarah E. Hamill, Review of Legal History, 28 Soc. \& LEGAL STUD. 538 (for a recent review of legal history scholarship).

${ }^{36}$ See generally, Michael Lobban, Introduction: The Tools and Tasks of the Legal Historian, in 6 ANDREW LEWIS \& MICHAEL LobBan, LAW AND History: CuRRENT Legal Issues 2003 (2004) (including recent attempts in legal history to give a voice to "the other").

${ }^{37}$ See, for example, Hedges \& WinterbotTom, supra note 33, where the authors went back to the Elizabethan statutes on wages and apprenticeships and also looked at gild regulations, gild customs and the laws regulating trade unions. The book ends with legislative reform proposals.

${ }^{38}$ K.W. Wedderburn, The Worker and the LaW (3d ed. 1986).

${ }^{39}$ Bob Hepple, Wedderburn's The Worker and the Law: An Appreciation, 34 Hist. STUd. ReL. 215, 223 (2013).

${ }^{40} I d$. at 218 .

${ }^{41}$ The third edition, published in 1986, included 200 pages on the history and analysis of the law on industrial conflict. See LORD WEDDERBURN, THE WORKER AND THE LAW (3 ${ }^{\text {rd }}$ ed. 1986).

${ }^{42}$ Hepple, supra note 39 , at 223.

${ }^{43}$ See generally Paul Davies \& Mark Freedland, Labour Legislation and Public Policy (1993).

${ }^{44} I d$. at 2 .

${ }^{45} \mathrm{Id}$. at 7.

${ }^{46}$ See generally K.D. Ewing, Trade Unions, the Labour Party, and the LAW (1982).
} 
laissez-faire by looking at the relationship between the state and industrial relations. ${ }^{47} \mathrm{He}$ used multiple sources, including government reports, Hansard minutes, TUC documents, and Labor Party documents in order to develop a nuanced understanding of the role of the state in British labor law. Douglas Brodie's A History of British Labor Law, published in 2003, also combined primary and secondary sources in order to analyze the purposes underlying particular legislative developments between 1867 and to compare this with the law's subsequent shape. ${ }^{48}$ Ruth Dukes, in The Labor Constitution, published in 2014, looked at the history of labor law scholarship and the enduring relevance of foundational texts to the study of labor law today rather than considering the historical development of labor laws as such. ${ }^{49}$ Despite the rich scholarly output that exists on British labor law history, a broader debate on methodological issues in the field, including the scope of the discipline, how to approach its study, and its overlap with other subjects, has hitherto been limited.

\section{Germany}

In Germany, labor law history finds its roots in legal history rather than labor history. ${ }^{50}$ As such, it sits less comfortably within a socio-legal framework, although early accounts of labor law history have been criticized for not giving due regard to social, economic and cultural factors which shaped labor law's development. ${ }^{51}$ Since the 1950s, scholars, starting with Theo Mayer-Maly, have moved beyond "pure" legal history to take account of the social context of labor law. ${ }^{52}$ Harald Steindl's edited collection in 1984, Wege zur Arbeitsrechtsgeschichte, ${ }^{53}$ attempted to respond to repeated calls amongst German scholars in the 1970s and earlier for the development of a comprehensive, socio-legal labor law history. ${ }^{54}$ His collection had the explicit aim of starting a dialogue between law and social and economic history. ${ }^{55}$ It contained chapters on a broad range of individual and collective labor laws in Germany and Austria, including contributions on social insurance. Drawing lessons from legal history, the collection tried to map different histories of labor in order to illustrate breaks and transformations of the law in a historical narrative. There was a recognition within the collection itself, however, that it could do no more than indicate different paths that scholars could take-which have so far not been fully explored by subsequent projects.

Individual scholars have continued to write on a broad range of topics: These include the historical development of the contract of employment, the juridification of labor relations, the

\footnotetext{
${ }^{47}$ See generally K.D. Ewing, The State and Industrial Relations: 'Collective Laissez-Faire’ Revisited, 5 HIST. STUD. INDUS. REL. 1 (1998).

${ }^{48}$ See generally Douglas Brodie, A History of British Labour LaW (2003).

${ }^{49}$ DUKEs, supra note 10.

${ }^{50}$ German legal history has a very different tradition compared to UK legal history. For methodological debates in German legal history see Marcel Senn, Rechtswissenschaft und Geschichte, in INTERDISZIPLINARITÄT IN DEN RECHTSWISSENSCHAFTEN INNEN UND AUSSPERSPECTIVEN (2012); Marcel Senn, The Methodological Debates in German-Speaking Europe (1960-1990), in Making Legal History. Approaches AND Methodologies (2012); Gerhard Oexle, Rechtsgeschichte und Geschichtswissenschaft, in AKTEN Des 26. DEUTSCHEN RechtShistorikertages Frankfurt A.M., $22 . \quad$ BIS 26. SEPTEMBER 1986 (1987); Ogorek, Rechtsgeschichte in der Bundesrepublik (1945-1990), in RECHTSWISSENSCHAFT IN DER Bonner Republik. Studien Zur Wissenschaftsgeschichte Der Jurisprudenz (Dieter Simon ed., 1994). Early legal histories which touched upon labor matters include Otto Von Gierke, Die Soziale Aufgabe Des Privatrechts (1894).

${ }^{51}$ Theo Mayer-Maly, Aufgabe und Probleme einer Geschichte des Arbeitsrechts Mayer-Maly, "Aufgabe und Probleme einer Geschichte des Arbeitsrechts", in DAS RECHT DER ARBEIT 126 (1956).

${ }^{52}$ Harald Steindl, Vorwort, in Harald Steindl, Wege Zur Arbeitsrechtsgeschichte viii (1984).

${ }^{53}$ Id.; Wilhelm Herschel, Arbeitsrecht in der Wohlfahrtsgesellschaft, in RECHT DER ARBEIT 402, 402 (1968) ("Die Geschichte des Arbeitsrechts - sie ist leider noch nicht geschrieben.").

${ }^{54}$ Franz Mestitz, Probleme der Geschichte des Arbeitsrechts. Ein Forschungsbericht für die Jahre 1974 bis 1979 , in Zeitschrift Fur Neuere Rechtsgeschitchte 47 (1980).

${ }^{55} \mathrm{Id}$. at $\mathrm{x}$.
} 
German labor constitution, the works constitution, the history of the labor courts, collective labor law, and labor law under National Socialism. ${ }^{56}$ Although Arbeitsrechtsgeschichte has not been subject to a sustained methodological discussion, there have been some attempts to define the field and appropriate research methods. ${ }^{57}$ Most works adopt a broad definition of "labor" (Arbeit) and "law" (Recht). There has been an intense debate over the "starting point" of labor law and the temporal scope of labor law history. ${ }^{58}$ In broad terms, research questions are underpinned by a regard for the question sociale. Taking its cue from legal history, they often rely on hitherto ignored archival materials. Franz Mestitz suggested that labor law needs to be understood as both expressing and shaping social reality. Taking such an approach allows for a problem-oriented, historical analysis of the discipline rather than a chronological retelling of developments. ${ }^{59}$ Joachim Rückert approached the history of labor law by looking at the legal solutions which have been found for particular problems at work over time and in different geographical locations in a holistic way. ${ }^{60}$ In 2020, Wolfgang Däubler and Michael Kittner published a historical study of the German works constitution (Betriebsverfassung), relying on a wide range of legal and other historical sources. They argued that as a central tenet of German history, the works constitution can only be properly understood taking into account the economic and political power struggles, as well as the formal laws and informal norms, which have shaped, and continue to influence, its form. ${ }^{61}$

Despite their different starting points, there is a recognition in Germany and the UK that labor law histories, if they are to do more than provide internal histories and account for the external forces which have shaped the law's development, are difficult to write and require scholars to, at the very least, engage with other disciplines, thereby opening up to socio-legal approaches. Labor law historians must also ask theoretical and methodological questions about their ability to research economic and social history if they have not had subject-specific training. ${ }^{62}$ Questions also arise on the scope-in terms of topic, place and time-of labor law history. Labor law's boundaries are nebulous. Harry Arthurs aptly describes labor law as emanating from "an infinity of sources, permeat[ing] all aspects of social and economic life, [it] is as much to be inferred as formally announced, and affects behavior, positively and negatively through social processes which are as varied as their context." 63 Problems of definition and scope inevitably arise in every field. However, the absence of an identifiable community of labor law historianslet alone of comparative labor law historians-has led to limited debate on "how to do" labor law history. In the next two sections, this Article seeks to kindle the debate by outlining the beginnings of a proposed socio-legal methodology for labor law history based on new approaches to comparative law, and drawing on historical sources and methods.

\footnotetext{
${ }^{56}$ Scholars include, amongst others, Thilo Ramm, Wolfgang Däubler, Gerd Bender, Joachim Rückert, Martin Becker, Martin Otto, Otto Kempen, Michael Kittner, and Thorsten Keiser.

${ }^{57} \mathrm{~A}$ particular example is the Initiative Arbeitsrechtsgeschichte; a cooperation between the Hugo Sinzheimer Institute and the Max Planck Institute for European Legal History. See Gerd Bender, Initiative History of Labour Law, MAX PLANCK INSTITUTE FOR EUROPEAN LEGAL HISTORY, https://www.rg.mpg.de/cooperations/hugo-sinzheimer-institut.

${ }^{58}$ See generally Franz Mestitz, Zur Mirkungsgeschichte Des Arbeitrechts in Steindl, supra note 54. See generally THORSTEN Keiser, Vertragsfreiheit Und Vertragszwang Im Recht Der Arbeit Von Der Frühen Neuzeit Bis In Die Moderne (2013).

${ }^{59}$ Mestitz, supra note 54 , at $8-9$.

${ }^{60}$ JoAchim RÜCKer, Arbeit Und Recht 1800: Historisch Und Verleichend, EuropäIsch Und Global (2014).

${ }^{61}$ Wolfgang Däubler \& Michael Kittner, Geschitchte Der Btriebsverfassung (2020).

${ }^{62}$ Some scholars have addressed this dilemma in relation to legal history. See Jonathan Rose, Studying the Past: the Nature and Development of Legal History as an Academic Discipline, 31 J. LEgAL HIst. 101 (2010). On law and history, see RoBERT W. Gordon, Taming the Past: Essays on LaW in History and History in LaW (2017).

${ }^{63}$ Harry Arthurs, Understanding Labour Law: The Debate over "Industrial Pluralism", 38 CURRENT LEgAL Probs. 83, 86 (1985).
} 


\section{Comparative Labor Law: Introducing a "Minor Comparativism" of Labor Law History}

Labor law is no stranger to comparative law. A large body of theoretical literature has developed on the proper application of the comparative method to labor law as well as an ever-increasing amount of literature comparing aspects of different legal systems. ${ }^{64}$ As Kahn-Freund pointed out, the objective of comparative labor law should be to discover whether an institution, practice, doctrine, or tradition is inevitable or universal, or whether it is the outcome of specific social, historical, or geographical conditions. ${ }^{65} \mathrm{~A}$ large portion of comparative writings seem to fall short of this objective by remaining superficial in the depth of comparison achieved. Their aim is to compare legal differences and similarities across jurisdictions. However, some works manage to conduct more thorough comparisons which convey a sense of how specific laws play out in a given society and provide an insight into how the law may be improved within that social setting. ${ }^{66}$

The main contribution to such "profound"67 comparative labor law stems from Otto Kahn-Freund. His dual legal background equipped him with the requisite socio-historical understanding of more than one legal system in order to carry out effective, in-depth comparisons. For Kahn-Freund, comparative labor law should not be seen as a separate field of research but as a tool of analysis. As Kahn-Freund pointed out:

$[O] n e$ of the virtues of legal comparison (which it shares with legal history) is that it allows a scholar to place himself outside the labyrinth of the minutiae in which legal thinking so easily loses its way and to see the great contours of the law and its dominant characteristics. ${ }^{68}$

This approach was applied in the 1970s by a group of leading scholars, under Bob Hepple's editorship, who attempted to explain labor law's pluralism by undertaking a comparative historical research project, published as The Making of Labor Law in Europe: A Comparative Study of Nine Countries up to 1945 in $1986 .{ }^{69}$ The project explained the historical development of labor law as resulting from "a process of struggle between different social groups ... and of competing ideologies conservatives, liberals and socialists, and of religious and secular groups. ${ }^{" 70}$ Labor law "is made by men and women in a society not of their own making." "I Its shape is dependent on the outcome of power struggles - what different social groups could "force or persuade other groups to let them have." 72

Hepple sought to explain the comparative development of labor laws at two levels: (1) The direct historical relationship of legal transplants from one country to another, and (2) the "inner" social, economic and political relationship of parallel developments in different countries. The first level is relatively straightforward: " $[\mathrm{M}]$ any rules of national systems of labor law are either derived

\footnotetext{
${ }^{64}$ David Ziskind, Labor Law Comparison in Perspective, 2 COMP. LAB. L. 209 (1977) (providing a good overview of these topics)

${ }^{65}$ See generally Otto Kahn-Freund, Labour Relations: Heritage and Adjustment (1979).

${ }^{66}$ See generally Matthew Finkin, Comparative Labour Law, in MATHIAS REIMANN \& REINHARD ZIMMERMANN, OXFORD HANDBOOK of COMPaRative LAW (2006) (giving an overview of the different types of comparative law); Roger Blanpain, Comparative labour LaW and industrial Relations in Industrialised Market Economies (2004); Anne Trebilcock, Handbook of Comparative Labour law (2018).

${ }^{67}$ Finkin categorizes writings on comparative labor law into five genres which are often overlapping: Descriptive, purposive, predictive, theoretical, and profound. See Finkin, supra note 66.

${ }^{68}$ Otto Kahn-Freund, Comparative Law as an Academic Subject, 82 L.Q. ReV. 40 (1966), at 40.

${ }^{69}$ See Bob Hepple, The Making of Labour Law in Europe: A Comparative Study of Nine Countries Up to 1945 (1986) [hereinafter Hepple (1986)]; see also Bob Hepple, The Transformation of Labour Law in Europe: A Comparative Study of 15 Countries 1945-2004 (2009) (the successor to Hepple's 1986 book).

${ }^{70}$ Hepple (1986), supra note 69, at 4.

${ }^{71} \mathrm{Id}$. at 1 .

${ }^{72} I d$.
} 
from or have been strongly influenced by other systems."73 The comparative law literature has long debated the viability and shape of legal transplants. ${ }^{74}$ Two main theoretical strands have emerged. For Watson, "a rule transplanted from one country to another ... may equally operate to different effect in the two societies, even though it is expressed in apparently similar terms in the two countries." 75 This implies that the transplantation of legal rules without adjustment of those rules is possible. Yet the success of rules borrowed from one legal system and directly imported to another system is rare. The second strand of thinking on the transplantability of legal rules stems from Otto Kahn-Freund. For Kahn-Freund, the degree to which a rule can be transplanted depends on the extent to which it conforms with the foreign political and legal structure. ${ }^{76}$ Thus, "we cannot take for granted that rules or institutions are transplantable ...; any attempt to use a pattern of law outside the environment of its origin [entails] the wish of rejection," unless legislators have adequate "knowledge not only of the foreign law, but also of its social, and above all its political, context."77

On the "inner relationship" between systems, Hepple argued that the development of labor law "is the product of a variety of historical factors, which are neither 'necessary' nor 'natural' .... The choices made were not inevitable solutions to the social problems created by the workings of the market." 78 The challenge for comparative labor lawyers is to explain the specific features of historical change. In Hepple's book, the individual chapters do this by looking at how particular legislative measures were introduced in each country through the lens of "power." For Hepple, "[m]any of the demands made by labour movements and social reformers were unsuccessful because they were unacceptable to those with greater economic and political power .... [T] he powerfulness of the opponents of reform was the decisive factor in the making of labor law."79 Adopting the lens of power in this sense allowed the contributors to portray the common tendencies and divergences of different labor law systems in nine European countries.

The question of whether and how to draw on other disciplines in order to undertake a comparison also permeates comparative law. Recent scholarship has sought to move away from what Pierre Legrand described as "positivist" comparative law, towards the contextualized analysis of legal rules, their active interpretation, and engagement with interdisciplinary study. ${ }^{80}$ As part of this trend, scholars have adopted different methodological lenses in order to give a voice to individuals and social groups whose views are not part of mainstream narratives. ${ }^{81}$ Their approach decenters the state and positive law as the focus of a comparison and recognizes the legitimacy of multiple traditions and social orderings. ${ }^{82}$ In an article published in 2015, Sherally Munshi borrowed from comparative literature to propose the idea of a minor comparativism, which engages

\footnotetext{
${ }^{73} I d$. at 2 .

${ }^{74}$ Authors who have written on transplantation include: ROGER BLANPAIN, COMPARATIVE LABOUR LAW AND INDUSTRIAL Relations In Industrialised Market Economies (8th ed. 2004); Otto Kahn-Freund, On Uses and Misuses of Comparative Law, 37 Mod. L. Rev. 1 (1974); Alan Watson, Legal Transplants: An Approach to Comparative Law (1974); Pierre Legrand, The Impossibility of Legal Transplants, 4 MAASTRICHT J. EuR. \& COMP. L. 111 (1997).

${ }^{75}$ WATson, supra note 74 , at 20.

${ }^{76} \mathrm{Kahn}$-Freund, supra note 74.

${ }^{77} I d$. at 27.

${ }^{78} I d$. at 4 .

${ }^{79} \mathrm{Id}$. at 5.

${ }^{80}$ See generally Pierre Legrand, Jameses at Play: A Tractation on the Comparison of Laws, 65 AM. J. CoMP. L. 1 (2017); as well as the other contributions in the 2017 special issue of the American Journal of Comparative Law.

${ }^{81}$ For an overview, see the Decolonial comparative law project led by Professor Dr. Ralf Michaels and Dr. Lena Salaymeh at the Max Planck Institute for Comparative and International Private Law (Hamburg). Ralf Michaels \& Lena Salaymeh, Decolonial Comparative Law, Max Planck Institute (2020) https://www.mpipriv.de/decolonial.

${ }^{82}$ Thus, there are some similarities between the arguments made in favor of transnational history to correct the focus by comparative historians on the nation state. See generally Jürgen Kocka, Comparison and Beyond 42 HIST. \& THEORY 39 (2003); Ian Tyrell, Reflections on the Transnational Turn in United States History: Theory and Practice, 4 J. GLOB. HIST. 453 (2009).
} 
"the essential instability, incoherence, alterity, and heterogeneity that define the state." ${ }^{83}$ A minor comparativism retains the general tenor of comparative law, which is "to reveal something about our immediate world that would not reveal itself but through the practice of adopting a foreign perspective", but it seeks that foreign perspective "within" one's own country. ${ }^{84}$ It "sets the official image of a particular state against the reflections of its minority subjects." ${ }^{85}$ A minor comparativism acknowledges that the minority - to be understood in the sense of foreign or not belonging to the majority - is not peripheral but central to the formation of laws, the state, and the nation. A minority constructs its thinking not within a national culture but apart from it-without absorbing a nation's consciousness, morality, or worldview. ${ }^{86}$ Adopting such a minority perspective decenters the state, thereby engaging "the essential instability, incoherence, alterity, and heterogeneity that define the state." 87 It recognizes that the state incorporates diverse peoples and views, and "severs the imagined unity between the state and its subjects." 88 A consequence of this is that a minor comparativism resists regurgitating authorized representations of the law. While traditional approaches to comparative law tend to identify and isolate particular rules or institutions across legal systems, a minor comparativism focuses on discovering how the law is encountered, shaped, and perceived by the minority. It seeks to complicate received understandings of the law and its development. For labor lawyers, the use of such an approach opens up traditional narratives to reinterpretation at a time when the discipline is in flux. As Munshi explains:

The purpose of such investigation is not merely ethnographic or to thicken our account of a culture, but liberatory. By recognizing that authoritative declarations of law do not exhaust our own understanding or experience of law, we proliferate opportunities to transform the laws that give shape and meaning to our shared circumstances. ${ }^{89}$

The question arises as to who is meant by "the minority" for labor law scholars. Two possibilities arise. First, Hepple, in his comparative labor law study, recognized that labor law's shape is dependent on the outcome of power struggles. The views of the individuals or groups who lost out in the power struggles - social reformers and labor movements who were unsuccessful—have been erased from the legal record and, by extension, are the subject of study of legal or labor historians, but are often neglected by comparative law and labor law scholars. Yet, their demands held sway at particular moments in history even if they were not in the end translated into law - the outcome of power struggles were neither inevitable nor predetermined. Second, there are the views of minority groups within states who observe majority culture but are not part of it. These minority groups are more frequently studied by historians than by lawyers, yet their perspectives offer valuable insights on the functioning of law in society.

A minor comparativism allows labor law scholars to rediscover both of these viewpoints, thereby disrupting and complicating received understandings of labor law's historical development. Such an exercise requires scholars to engage seriously with the discourse of foreign minorities and to set it against the traditional narrative. This, in turn, enables scholars to identify, question, and challenge conventional assumptions about the legal system by rendering those conventional assumptions foreign to themselves. Such an approach has not hitherto been applied to labor law. It allows scholars to

\footnotetext{
${ }^{83}$ Munshi, supra note 9, at 665 (citing Pierre Legrand, Issues in Translatability of Law, in NATION, LANGUAGE, AND THE ETHiCs of Translation (2005)).

${ }^{84} I d$. at 664 .

${ }^{85} \mathrm{Id}$. at 665 .

${ }^{86} I d$. at 667 (citing Giles Deleuze \& Felix Guattari, Kafka: Toward a Minor Literature (Dana Polan trans., 1986)).

${ }^{87} \mathrm{Id}$. at 666.

${ }^{88} \mathrm{Id}$.

${ }^{89} \mathrm{Id}$.
} 
consider the possibilities of what could have been, to think about law in a different framework from the norm, and to develop alternative approaches to legal regulation. In a final section, I begin to develop a minor comparativism of labor law history within a socio-legal framework with a view to revealing alternative ways of thinking about worker participation in workplace decision-making in the UK and Germany.

\section{E. Developing a Minor Comparativism of Labor Law History: "Foreign" Views on Worker Participation in Workplace Decision Making}

Labor law's essential form reflects the problems occasioned by industrialization, including the separation of production from consumption and of workers from ownership and control of the means of production. ${ }^{90}$ For much of the twentieth century, worker representation within the workplace in the UK had been assured primarily through agreement between employers and trade unions outside a formal legislative footing. ${ }^{91}$ The dominant view in British labor law justifying the lack of workers' formal involvement in the control of industry has been intertwined with collective laissez-faire in that worker representation on management boards was "unacceptable" as it threatened trade-union independence. ${ }^{92}$ For most of the twentieth century, worker participation on company boards was also anathema to corporate law's model of shareholder ownership and primacy. Since the 1990s, corporate law scholars have shown resurgent interest in protecting "stakeholder rights"-broadly defined to include workers, consumers and other interest groups - through corporate governance reforms, including providing for worker and other stakeholder representation on company boards. ${ }^{93}$ In contrast, there has been comparatively limited engagement by labor law scholars with labor law's role in providing for worker participation in workplace decision-making. Much of the British labor law literature which discusses worker representation focuses on the Report of the Committee of Inquiry on Industrial Democracy (1977) Cmnd 6706 (the "Bullock Report"). For those arguing in favor of worker participation, the German model of parity codetermination (paritätische Mitbestimmung), which provides for equal worker and management representation on certain company supervisory boards, is cited as exemplary, ${ }^{94}$ without probing the principles and historical contingencies underpinning the system. ${ }^{95}$ British labor law is lacking a debate about what workplace participation is for and what it should look like.

\footnotetext{
${ }^{90}$ Simon Deakin \& Frank Wilkinson, The Law of the Labour Market: Industrialization, Employment, AND LEgal Evolution Ch. 2 (2005).

${ }^{91}$ See generally Ruth Dukes, Voluntarism and the Single Channel: The Development of Single-Channel Worker Representation in the UK, 24 INT'L J. COMP. LAB. L. \& INDUS. REL. 87 (2008).

${ }^{92}$ H.A. Clegg, A New Approach to Industrial Democracy 22 (1960). Since 1993, the adoption of several EU directives requiring information and consultation of employees has introduced, in certain circumstances, information and consultation channels for worker representatives. However, the impact of these measures has been limited. See generally Dukes, supra note 91.

${ }^{93}$ See generally Zoe Adams \& Simon Deakin, Corporate Governance and Employment Relations, in THE OXFORD HaNDBOOK OF CoRporate LAW AND Governance (2018).

${ }^{94}$ In 2016, upon becoming Prime Minister, Theresa May pledged to appoint workers to company boards with a view to diversifying boardrooms, controlling executive pay, and scrutinizing management decision-making. See Nils Pratley, Theresa May's plan to put workers in boardrooms is extraordinary, THE GUARDIAN (Jul. 11, 2016, 11:47 AM), https://www.theguardian. com/politics/nils-pratley-on-finance/2016/jul/11/theresa-may-plan-workers-boardroom-reform-extraordinary-tories. In 2013, Frances O'Grady, the General Secretary of the TUC argued that worker representation through trade unions was justified on the basis that "economic strength demands economic democracy, a recalibration of the relationship between capital and labour." Frances O'Grady, Attlee Memorial lecture, TUC (Apr. 26, 2013), http://www.tuc.org.uk/union-issues/francesogradys-atlee-memorial-lecture.

${ }^{95}$ Codetermination ("Mitbestimmung") is an umbrella term which describes a body of different practices that take place under law in the individual enterprises of industry, commerce, and trade, and which require joint decision-making by labor and management representatives in the control and conduct of an enterprise either. Of these, the system of parity codetermination ("paritätische Mitbestimmung") stands out for providing the greatest level of involvement for workers by allowing for equal representation of employees and management on the supervisory boards of companies in certain industries
} 
A minor comparativism within a socio-legal framework can ignite such a debate by revealing alternative ways of thinking about worker participation. The approach combines archival research with an analysis of German and British literature drawn from labor and corporate law, history, and industrial relations in order to reconstruct and reassess historical debates on worker participation through a minority lens. This enables an analysis of worker participation within a different framework from the status quo, opening it up to other possibilities. It moves away from mainstream explanations of the law's development and, instead, focuses on the law's perception at its time of coming into being by the minority - as evidenced by archival sources. A minor comparativism in this case sets the mainstream narrative that worker participation is "unacceptable" against the debates that were taking place in the UK on worker participation during and immediately after the period of the Second World War, up to 1950. Two minority perspectives are of interest. First, that of a group of exiled German trade unionists based in the UK during World War II who combined to form the Trade Union Centre for German Trade Unionists in the UK (Landesgruppe deutscher Gewerkschafter in Grossbritannien). A close reading of the German literature ${ }^{96}$ suggests that the post-war German model of codetermination, initially introduced by the British military government in the iron and steel industries in 1947, is based on plans designed by the Landesgruppe. ${ }^{97}$ The Landesgruppe's chairman, Hans Gottfurcht ${ }^{98}$-a German Jewish trade unionist who fled to the UK in 1938 - set up a number of working groups during the war to develop plans for post-war German reconstruction. The Landesgruppe was the only German emigrant body that brought together and represented all leftwing exile groups. ${ }^{99}$ One of these groups, the Internationaler Sozialistischer Kampfbund (ISK), had a substantial, albeit hitherto unexplored, influence on Landesgruppe policies - and had close links with British intellectuals, including the industrial relations scholar Allan Flanders, throughout the 1920s, 1930s, and 1940s. ${ }^{100}$ Letters exchanged between Landesgruppe members and British trade unionists, including Walter Citrine, the Secretary General of the Trades Union Congress (TUC), and Ernest Bevin, the Minister for Labor (1940-1945) and Foreign Secretary (1945-1951), before, during, and after the war, are indicative of close personal relationships. Many German post-war trade union leaders were exiled in the UK during the war and had been members of the Landesgruppe. As such, the Landesgruppe is an example of a minority within, but apart from, and not of, the British labor law tradition. An exploration of their deliberations on worker participation also raises the question of whether there was any cross-fertilization of ideas between the British and exiled German trade union movements which have hitherto escaped scholars' attention.

The second minority perspective is that of a number of British trade unionists who advocated worker participation in workplace decision-making throughout the 1940s. The subject of worker representation on boards had arisen repeatedly at TUC Annual Congresses throughout the 1920s, 1930s, and early 1940s in the context of debates on the future nationalization of British industry. Nationalization of, inter alia, the coal, iron, and steel industries formed a major part of the election manifesto of the Labor government which came to power in July 1945. The general question that was raised for British trade unions by the nationalization program was whether unions would, or should, be prepared to take a wider role in the management of these nationalized industries.

and above specific size thresholds. It is widely regarded in German literature as a successful trade-union achievement and a vital element, and even as the most important "socio-political innovation" of German post-war industrial democracy. HorST Thum, Mitbestimmung In Der Montanindustrie (1982), 11-37; Gloria Müller, Mitbestimmung In Der NACHRIEGSZEIT (1987), 113-46.

${ }^{96}$ See generally EBERHARD SCHMIDT, DIE VerHINIDERTE NEUORDNUNG 1945-1952 (1977).

${ }^{97} \mathrm{Id}$.

${ }^{98}$ See generally UrusLa BitZegeio, ÜBer PARTEI- Und LANDESGRENZEN HINAUS: HANS GotTFURCHT (1896-1982) UND DIE GEWERKSCHAFTLICHE ORganisation DER ANGESTELlten (2009).

${ }^{99}$ See generally LudWig EIBER, Die SozIALDEMOKRATEN IN DER EMIGRATION (1998).

${ }^{100}$ For an overview, see Sabine Lemke-Müller, Ethischer Sozialismus Und Soziale Demokratie. Der Politische WEG Willi EISCHLERS VOM ISK ZUR SPD (1988). 
However, in practice it became clear that the TUC generally was prepared to take only the most cautious steps in this direction despite a number of affiliates advocating a different, and after 1945, increasingly vocal stance which has largely been forgotten. ${ }^{101}$

Viewing the dominant narrative on worker participation through these minority eyes provides new perspectives on the subject. It is liberating in the sense that it transforms the way in which worker participation can be understood within the UK labor law framework and provides different starting points to develop a contemporary model for worker participation-grounded in labor law, and appropriate for a post-industrial landscape.

The minor comparativism proposed here takes place within a socio-legal framework. It does not seek primarily to document the origins of particular laws or legal concepts, but instead seeks to rediscover the views of two minority groups who were advocating in favor of worker participation in workplace decision-making at a critical time in British labor law history, but whose views have escaped the legal record. The comparativism relies on a wide range of German and British primary and secondary sources drawn from labor law, history, and industrial relations in order to reconstruct the Landesgruppe's deliberations on worker participation and their interactions with British trade unionists on the subject. Archival sources, which are held in archives in Germany and the UK, ${ }^{102}$ include documents from the British military government, correspondence between British and exiled German trade unionists, diaries of exiled trade unionists, and minutes of Landesgruppe meetings. Archival sources have been under-used in British labor law history, although they form the backbone of legal historical research. As Boorstin points out, "history is the data of law." 103 It allows the legal scholar to discover the "minds, intentions, problems, and limitations of those who created [it] or for whom [it was] created." ${ }^{104}$ By using archival sources, scholars can revisit classic accounts of the development of the theories and processes underpinning the labor law system. ${ }^{105}$ For lawyers, the opening up of their discipline to the findings of historians and to new methods of comparative law allows a more empirically refined and a theoretically sounder understanding of the socio-legal history and nature of labor law.

\section{F. Conclusion}

There is a long history of socio-legal labor law scholarship in Germany and the UK, and labor law historians have recognized that, in order to trace the influences and processes which explain labor law's development, they must be open to using a broad range of sources. Yet methodological debates on "how to do" labor law history, and the discipline's links with socio-legal studies, have been limited in Germany and the UK. This Article has considered how history, when applied within a socio-legal comparative framework, can provide an entrée into different ways of thinking about labor law and labor relations systems. It has proposed a minor comparativism of labor law history, based on archival materials and drawing on legal, historical, and industrial relations

\footnotetext{
${ }^{101}$ See generally Rebecca Zahn, German Codetermination Without Nationalization, and British Nationalization Without Codetermination: Retelling the Story 36 Hist. STUD. INDUST. REL. 1 (2015). Hugh Clegg elaborates three principles underpinning industrial democracy which, according to him, crystallized in the inter-war years, and which provide an explanation as to why codetermination never took root in the UK: First, trade unions must be independent of the state; second, trade unions can only represent the industrial interests of workers; and, third, the ownership of industries is irrelevant to good industrial relations. See Clegg, supra note 92, at 21-25. Clegg argues that workers' representation in management or their involvement in the control of industry does not therefore form a fundamental underpinning of industrial democracy and is indeed "unacceptable" as it threatens trade-union independence. Id. For a broader overview see HUGH CLEGG, INDUSTRIAL DEMOCRACY AND NATIONALIZATION (1951).

${ }^{102}$ Primarily in the Modern Records Centre (University of Warwick), the National Archives (Kew), the Bundesarchiv (Koblenz) and the Archiv der sozialen Demokratie/DGB Archiv (Friedrich-Ebert-Stiftung, Bonn).

${ }^{103}$ Daniel Boorstin, Tradition and Method in Legal History, 54 HaRV. L. ReV. 424, 427 (1941).

${ }^{104}$ Robert Bartlett, History and Historians: Selected Papers of R.W. Southern 104-05 (2004).

${ }^{105} \mathrm{On}$ the value of law and history generally, see Rose, supra note 62 .
} 
literature in order to shed new light on conventional assumptions about worker participation in workplace decision-making in the UK. A minor comparativism unearths hitherto neglected perspectives - those that have escaped the legal record-thereby opening up traditional narratives to new interpretations. As applied to worker participation in workplace decisionmaking, it provides the basis for a contemporary debate about what workplace participation is for and what it should look like. Finally, in proposing a socio-legal methodology for labor law history, this Article hopes to begin a debate, in the spirit of the subject of this special issue, on the theoretical and methodological contours of German and British labor law history and its possible links with socio-legal approaches. 